\title{
Thermodynamics of host-guest interactions: Solubility enhancements
}

\author{
Angela F Danil de Namor \\ Chemistry Department, University of Surrey, Guildford, Surrey, GU2 5XH, \\ United Kingdom
}

\begin{abstract}
One of the most important properties of synthetic macrocyclic hosts such as cryptands is their ability to interact with metal cation guests.

Therefore, a summary of the thermodynamics of cation-cryptand complexation reactions in different media is given. This is followed by recent thermodynamic studies aiming to investigate the host properties of synthetic (crown ethers and cryptands) and natural (cyclodextrins) macrocyclic hosts towards substrates of biological relevance. The importance of transfer data for the host and guest components of the system among different reaction media in the interpretation of complexation processes involving macrocyclic hosts is demonstrated. The effect of macrocyclic ligands on the solubility of amino acids in non-aqueous media is shown.
\end{abstract}

\section{INTRODUCTION}

In the past three decades a large number of macrocyclic ligands with host properties towards inorganic and organic guests have been prepared and investigated. The syntheses of crown ethers by Pedersen in 1967 (refs $1 \& 2$ ), cryptands by Lehn in 1973 (refs $3 \& 4$ ) and spherands by Cram in 1974 (ref 5-7) have opened the way for new developments in the area of macrocylic chemistry. These synthetic hosts and other related molecules as well as natural macrocyclic ligands have shown interesting and unusual binding properties mainly due to the presence of molecular cavities able to interact with a large number of charged and uncharged guests. Several reviews and books in the area of macrocyclic chemistry have been published (ref 8-15). The forces which contribute to the stabilisation of the complexes formed between macrocyclic hosts and guests are of a non-covalent nature. Undoubtedly, thermodynamics is a powerful tool for the study of host-guest interactions in solution. Thermodynamic data involving macrocyclic ligands are mostly referred to the complexation process involving these ligands and guest species. Often, these data are limited to stability constant measurements (hence free energy of complexation). There is no doubt that the solvation properties of the host and guest play a significant role in the process of complexation.

The differences in solvation of a solute (host or guest) between two solvents are reflected in the thermodynamic parameters of transfer (free energy, $\Delta_{t} G^{\circ}$, enthalpy, $\Delta_{t} H^{\circ}$ and entropy, $\Delta_{t} S^{\circ}$ ). Therefore, independently of the host-guest system under study, transfer data among different reaction media for the host and the guest components of the system are key parameters in the interpretation of the binding process involving macrocyclic ligands. These parameters are currently derived from solubility and calorimetric measurements. This paper illustrates how transfer data has helped in the understanding of complexation processes involving synthetic (crown ethers and cryptands) and natural (cyclodextrins) macrocyclic hosts with different guests in several reaction media.

\section{CATION (I). CRYPTAND COMPLEXATION - SINGLE-ION VALUES}

The complexing abilities of cryptands and crown ethers (Fig 1) towards metal ions is one of the most important properties of these ligands.
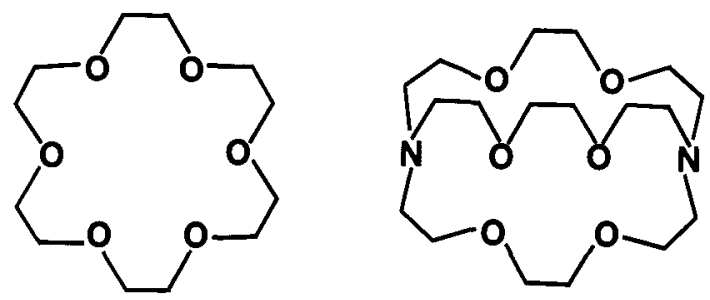

FIG. 1. Structures : 18-Crown-6 and Cryptand 222 
The thermodynamics of cation-coronand complexation reactions in different media have been the subject of a considerable number of publications. The main contribution in this area is due to Izatt, Christensen and co-workers (ref 10). These authors have successfully demonstrated the potential use of titration calorimetry in the determination of stability constants and enthalpies of complexation between crown ethers and uni and multivalent cations in various solvents. However, the generation of stability constant data from titration calorimetry is limited to stability constant $\left(\log K_{s}\right)$ values between 1 to $6 \log$ units.

Cryptands generally form 1:1 complexes with metal cations in solution. These complexes are known as metal ion cryptates (eq. 1).

$$
\mathrm{M}^{\mathrm{n}+}(\mathrm{s})+\operatorname{Cry}(\mathrm{s}) \longrightarrow \mathrm{M}^{\mathrm{n}+} \operatorname{Cry}(\mathrm{s})
$$

Stability constants for the complex formation between cryptands and metal ions are generally greater than corresponding data for cation-coronand complexation reactions in a given solvent (ref 10 ). Therefore these values, particularly in non-aqueous media cannot be generally obtained from titration calorimetry data. Most stability constant data for cation-cryptand complexation reactions are the result of potentiometric titrations. The most currently used method involves a competition reaction between the silver cation and metal ions with cryptands. This technique, extensively used by Cox and Schneider (refs $16 \& 17$ ) has been most useful for stability constant measurements. Data on enthalpies of complexation of metal (I) cations and cryptands mainly in dipolar aprotic media determined calorimetrically have been reported by us (ref 18-22). Solvents characterised by their low solubility in water which can therefore be used for direct partition of electrolytes were included in our studies.

A considerable amount of effort has been directed to the establishment of conventions which could be used for the calculation of single ion quantities for transfers from a reference solvent ( $s_{1}$ ) to any other solvent $\left(\mathrm{s}_{2}\right)$. The importance of single ion values have been emphasised by several workers (ref 23-26). The thermodynamic parameters for the transfer of electrolytes $\left(\mathrm{M}^{+}+\mathrm{X}^{-}\right)$among two solvents involve the contribution of the cation and the anion. Therefore, it is convenient to split the thermodynamic quantities of transfer into single-ion contributions. The various extra thermodynamic conventions proposed in the literature and the reliability of the single ion values derived from these conventions have been discussed by Marcus (ref 26). The most widely used convention is that proposed by Parker and co-workers (ref 27) known as the $\mathrm{Ph}_{4} \mathrm{AsPh}_{4} \mathrm{~B}$ convention. As pointed out before, it is not possible to know whether or not a convention is valid but certain confidence is gained when similar single ion values of transfer are obtained by using different extra thermodynamic conventions.

The Lejaille (cryptand) conventions (refs 28 \& 29) states that:

a) The transfer enthalpy, $\Delta_{t} H^{\circ}$ (free energy or entropy) of a metal ion cryptate [M+Cry] from a reference solvent $\left(s_{1}\right)$ to another solvent $\left(s_{2}\right)$ is equal to the transfer enthalpy of the uncomplexed host ligand (Cry) as represented by and

$$
\Delta_{\mathrm{t}} \mathrm{H}^{\circ}[\mathrm{M}+\mathrm{C} \text { ry }]\left(\mathrm{s}_{1} \rightarrow \mathrm{s}_{2}\right) \cong \Delta_{\mathrm{t}} \mathrm{H}^{\circ}[\mathrm{Cry}]\left(\mathrm{s}_{1} \rightarrow \mathrm{s}_{2}\right)
$$

b) The transfer enthalpy (free energy or entropy) of a metal-ion cryptate from a reference solvent to another is equal to zero

$$
\Delta_{\mathrm{t}} \mathrm{H}^{\circ}[\mathrm{M}+\mathrm{Cry}]\left(\mathrm{s}_{1} \rightarrow \mathrm{s}_{2}\right) \stackrel{\cong}{=} 0
$$

The implications of these conventions in the calculation of single ion values for the uncomplexed cations is best illustrated by considering the following thermodynamic cycle (ref 30 )

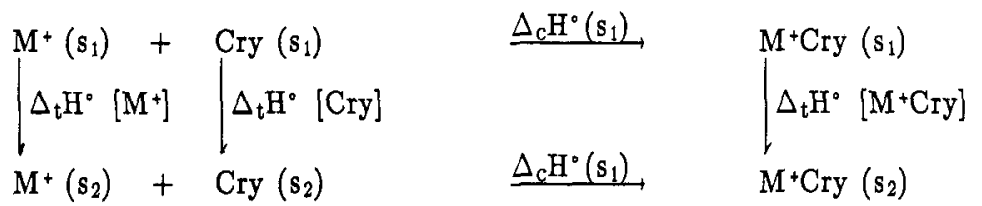

In this cycle, $\Delta_{\mathrm{c}} \mathrm{H}^{\circ}$ and $\Delta_{\mathrm{t}} \mathrm{H}^{*}$ are the enthalpies of complexing and transfer respectively in or from a reference solvent $\left(s_{1}\right)$ to any other solvent $\left(s_{2}\right)$. It is quite clear from this cycle that the validity of convention (a) (eq. 3 ) implies that:

$$
\Delta_{\mathrm{c}} \mathrm{H}^{\bullet}\left(\mathrm{s}_{2}\right)-\Delta_{\mathrm{c}} \mathrm{H}^{\bullet}\left(\mathrm{s}_{1}\right) \cong \Delta_{\mathrm{t}} \mathrm{H}^{\bullet}\left[\mathrm{M}^{+}\right]\left(\mathrm{s}_{1} \rightarrow \mathrm{s}_{2}\right)
$$

We have demonstrated in several publications that eq. 5 holds remarkably well in terms of enthalpy among dipolar aprotic solvents. The validity of eq. 5 in terms of free energy has also been shown in these solvents (ref 31-33). By inserting quantities in the thermodynamic cycle (eq. 4) a representative example in terms of enthalpy is given for the lithium-cryptand 222 (222) system using propylene carbonate, $\mathrm{PC}$ (reference solvent) and nitromethane $\left(\mathrm{MeNO}_{2}\right)$. 


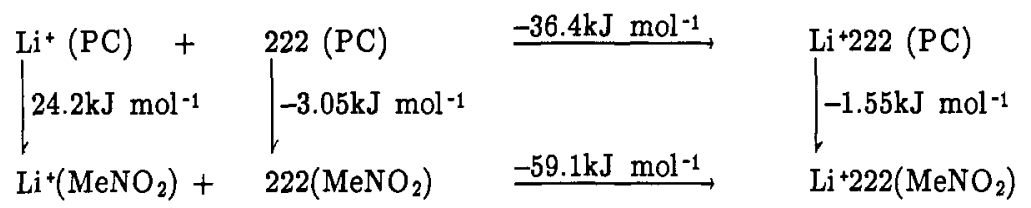

On the basis of experimental data involving a wide range of solvents, it was concluded that eq. 5 can be used for the calculation of single ion values of transfer of univalent cations among dipolar aprotic solvents.

As far as anions are concerned, the implication of identity (4) is that,

$$
\Delta_{\mathrm{t}} \mathrm{H}^{\bullet}\left[\mathrm{M}^{+} \mathrm{Cry}\right] \mathrm{X}^{-}\left(\mathrm{s}_{1} \rightarrow \mathrm{s}_{2}\right)=\Delta_{\mathrm{t}} \mathrm{H}^{\bullet} \mathrm{X}^{-}\left(\mathrm{s}_{1} \rightarrow \mathrm{s}_{2}\right)
$$

Eq. 7 has been successfully applied for the calculation of single ion quantities for univalent anions among dipolar aprotic solvents (ref 34 ). Work is now in progress to derive single ion quantities for multivalent anions (ref 35). A correlation between entropies of complexation, $\Delta_{\mathrm{c}} \mathrm{S}^{\circ}$ of cryptands (cryptand 222 and dibenzo cryptand 222) with univalent cations in non-aqueous media and entropies of solvation, $\Delta_{\text {solv }} S^{\circ}$ of these cations in these media, has been recently shown (ref 21). This correlation has emerged as a result of the values (almost constant) for the entropy of cryptate formation, $\Delta_{\mathrm{cf}} \mathrm{S}^{\circ}$ of several univalent cations and cryptands in various solvents. $\Delta_{\mathrm{cf}} \mathrm{S}^{\circ}$ data are referred to the process,

$$
\mathrm{M}^{+} \text {(gas) }+\operatorname{Cry}(\mathrm{s}) \longrightarrow \mathrm{M}^{+} \mathrm{Cry}(\mathrm{s})
$$

which is essentially the transfer of the cation $\left(\mathrm{M}^{+}\right)$from the gas phase to the solvated host to give the solvated cryptate. Representative $\Delta_{c f} S^{\circ}$ data for alkali-metal cations and cryptand 222 in three dipolar aprotic solvents (refs $19 \& 32$ ) are given in Table 1.

TABLE 1. Entropies of cryptate formation (eq. 8) of univalent cations and cryptand 222 in dipolar aprotic media at $298.15 \mathrm{~K}$

\begin{tabular}{lccc}
\hline & \multicolumn{3}{c}{$\Delta_{\mathrm{cf}} \mathrm{S}^{\circ} / \mathrm{JK}^{-1} \mathrm{~mol}^{-1}$} \\
Cation & $\mathrm{PC}$ & $\mathrm{MeCN}^{\mathrm{a}}$ & $\mathrm{MeNO}_{2}^{\mathrm{a}}$ \\
$\mathrm{Li}^{+}$ & -209.6 & -218.4 & -209.6 \\
$\mathrm{Na}^{+}$ & -213.0 & -234.3 & -216.7 \\
$\mathrm{~K}^{+}$ & -206.3 & -215.5 & -204.6 \\
$\mathrm{Rb}^{+}$ & -219.2 & -227.6 & -227.2 \\
$\mathrm{Cs}^{+}$ & -216.3 & -228.9 & -221.3 \\
\hline
\end{tabular}

a MeCN $=$ acetonitrile and $\mathrm{MeNO}_{2}=$ nitromethane

The entropy of cryptate formation, $\Delta_{\mathrm{cf}} \mathrm{S}^{\circ}$ may be expressed in terms of the entropies of hydration, $\Delta_{\mathrm{h}} \mathrm{S}^{\circ}$, transfer, $\Delta_{\mathrm{t}} \mathrm{S}^{\circ}$ and complexation, $\Delta_{\mathrm{c}} \mathrm{S}^{\circ}$. Thus,

$$
\Delta_{c f} S^{\circ}=\Delta_{h} S^{\circ}\left(M^{+}\right)\left(\text {gas } \rightarrow \mathrm{H}_{2} \mathrm{O}\right)+\Delta_{t} S^{\circ}\left(M^{+}\right)\left(\mathrm{H}_{2} \mathrm{O} \rightarrow \mathrm{s}\right)+\Delta_{c} \mathrm{~S}^{\circ}(\mathrm{s})
$$

In eq. 9 , the entropy of solvation, $\Delta_{\text {solv }} S^{\circ}$ is the sum of these two contributions,

$$
\Delta_{\mathrm{solv}} S^{\circ}=\Delta_{\mathrm{h}} \mathrm{S}^{\circ}+\Delta_{\mathrm{t}} \mathrm{S}^{\circ}
$$

Therefore,

$$
\Delta_{\mathrm{cf}} \mathrm{S}^{\bullet}=\Delta_{\mathrm{solv}} \mathrm{S}^{\bullet}+\Delta_{\mathrm{c}} \mathrm{S}^{\bullet}(\mathrm{s})
$$

Since the $\Delta_{c f} S^{\circ}$ values (Table 1) may be considered constant, the following correlation holds;

$$
\Delta_{c} S^{\circ}(\mathrm{s})=\text { const }-\Delta_{\text {solv }} \mathrm{S}^{\circ}
$$

The validity of eq. 12 provides a strong indication that the solvation of the guest cation plays a predominant role in the complexation process involving univalent cations and cryptands in non-aqueous media. Further implications based on eq. 12 have been discussed elsewhere for these systems (ref 21 ).

\section{CATION (III) - CRYPTAND COMPLEXATION}

To date, there has been only limited information on single ion values for the transfer of multivalent ions from water or any other reference solvent to non-aqueous media (ref 36). Therefore, it is important to test whether or not the cryptate conventions (eqs. $2 \& 3$ ) can be used to derive single-ion quantities for multivalent cations. Thermodynamic studies of complexation of divalent cations and cryptands have been mostly limited to stability constant (hence free energy) measurements. Enthalpy data on these systems are indeed very scarce. 
We are currently working with alkaline-earth metal ions and cryptands in dipolar aprotic media (ref 37 ), but we do not have yet enough information as to indicate whether or not these conventions are valid for these systems. Thermodynamic studies of lanthanide (III) cryptands (cryptand 222 and 221 ) in dipolar aprotic media (propylene carbonate and acetonitrile) (ref 38) permit us to draw some conclusions regarding the validity of the cryptate conventions for the calculation of single ion values for the transfer of tervalent cations among these solvents. A representative example via the cycle (eq. 6) is given for the $\mathrm{La}^{3+}$ cryptand 222 system

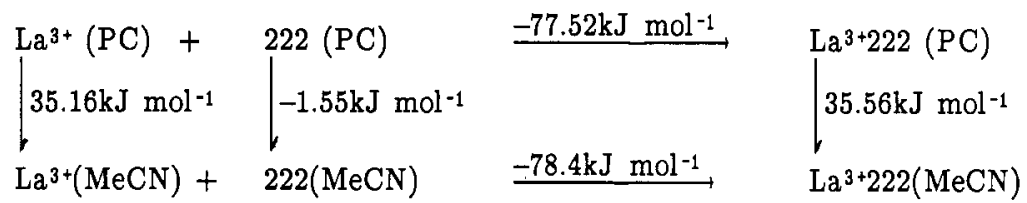

$\Delta_{t} \mathrm{H}^{\circ}$ values given in the cycle for $\mathrm{La}^{3+}$ and $\left[\mathrm{La}^{3+222]}\right.$ cations have been derived from independent measurements of heats of solution of electrolytes containing the appropriate cation in the relevant solvent. The single-ion values are based on the $\mathrm{Ph}_{4} \mathrm{AsPh}_{4} \mathrm{~B}$ convention. It must be emphasised that the relative transfer for these cations is independent of any extra thermodynamic convention. A very clear picture emerges from the data given for this system showing that:

$$
\Delta_{\mathrm{t}} \mathrm{H}^{\circ} \mathrm{La}^{3+}(\mathrm{PC} \rightarrow \mathrm{MeCN}) \stackrel{ }{=} \Delta_{\mathrm{t}} \mathrm{H}^{\circ} \mathrm{La}^{3+222}(\mathrm{PC} \rightarrow \mathrm{MeCN})
$$

These findings strongly suggest that whether through the ligand or by direct interaction, the solvents are able to recognise selectively the uncomplexed cation. Therefore, I conclude that, unlike for cation (I) - cryptand systems, the Lejaille conventions (eqs. $2 \& 3$ ) are not valid for the calculation of single ion values for the lanthanide cations among dipolar aprotic media.

\section{AMINO ACID-MACROCYCLIC COMPLEXATION. SOLUBILITY ENHANCEMENTS}

Host-guest interactions through hydrogen bond formation are an interesting aspect of the chemistry of crown ethers and cryptands. Complexation studies between crown ethers and ammonium and substituted ammonium salts have been reported (refs $39 \& 40$ ). Following the observation that the addition of crown ethers and cryptands to saturated solutions of amino acids in the alcohols significantly increases their solubility in these solvents, we proceeded with quantitative solubility studies. Fig. 2 shows the increase in the solubility of DL-phenylalanine in propan-2-ol as a function of the concentration of 18 crown 6 (ref 41 ).

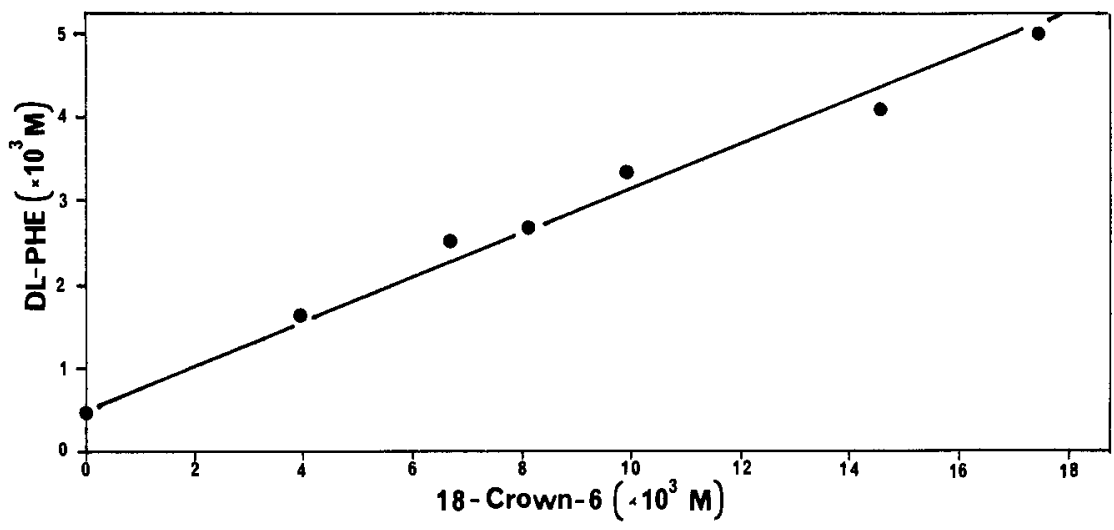

FIG. 2. Solubility of DL-phenylalanine in propan-2-ol as a function of the concentration of 18 crown 6 concentration at $298.15 \mathrm{~K}$

The nature of amino acid-18 crown 6 interactions was established from $\mathrm{pH}$ titrations and from calorimetric studies using $\mathbf{N}$ blocked amino acids. The results suggested that hydrogen bond formation takes place between the protonated- $\stackrel{+}{+} \mathrm{H}_{3}$ group and the donor atoms of the ligand. Amino acid 18 crown 6 complexes have been isolated and the thermodynamic parameters of solution determined. For an amino acid (AA) and an amino acid-18 crown 6 (AA18C6) in transfers from methanol to ethanol, it is generally observed that in terms of free energy

$$
\Delta_{\mathrm{t}} \mathrm{G}^{\circ}(\mathrm{AA})(\mathrm{MeOH} \rightarrow \mathrm{EtOH}) \cong \Delta_{\mathrm{t}} \mathrm{G}^{\circ}(\mathrm{AA} 1866)(\mathrm{MeOH} \rightarrow \mathrm{EtOH})
$$

These findings are in accord with the suggested model (Fig. 3) which shows that most of the amino acid molecule is directly exposed to the solvent. Further details on amino acid - 18 crown 6 and amino acid-cryptand 222 complexation reactions are detailed elsewhere (refs 41-43). 


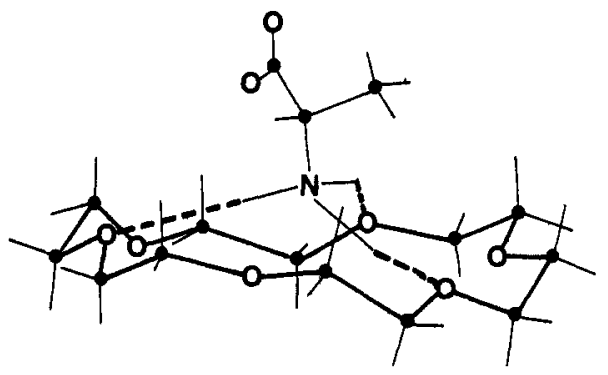

FIG. 3. Amino Acid-18-Crown-6 Interaction

\section{ANION-CYCLODEXTRIN COMPLEXATION}

Cyclodextrins are commonly constituted of $\operatorname{six}(\alpha)$, seven $(\beta)$ and eight $(\gamma)$ units of glucose. The applications of cyclodextrins in research and industry are numerous (refs 44-46). Of particular interest is the enhancement of solubility of drugs by cyclodextrins (ref $47 \& 48$ ).

We are not aware of any data reported on the thermodynamic parameters of transfer of cyclodextrins from water to non aqueous media. Thermodynamic data on cyclodextrin-substrate complexation reactions are mostly limited to water. Encouraged by the fact that cyclodextrins are able to form inclusion complexes as the antibodies, we selected for our studies a series of electrolytes containing anions constituents of antigenic determinants. These are the parahydroxyphenylazo and substituted parahydroxyphenylazobenzoate anions. Solvents chosen for these studies were $\mathrm{H}_{2} \mathrm{O}$ and $\mathrm{N}, \mathrm{N}$-dimethylformamide (DMF). The most striking feature of the thermodynnamic data is reflected in the $\Delta_{\mathrm{c}} \mathrm{H}^{\circ}$ and $\Delta_{\mathrm{c}} \mathrm{S}^{\circ}$ values obtained for these anions and cyclodextrins in these two solvents (refs $49 \& 50)$. Data for the $p$ (parahydroxyphenylazo) benzoate [ $\left.p\left(\mathrm{pOHPhN}_{2}\right) \mathrm{B}^{-}\right]$(refs 51 \& 52 )

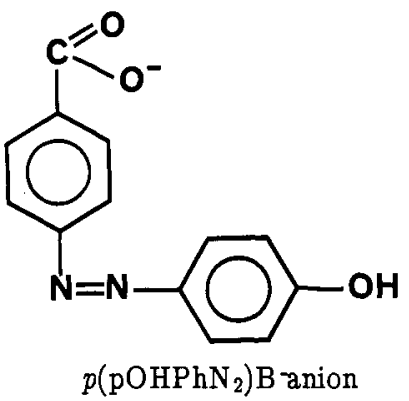

and two cyclodextrins (CD), $\alpha$ and $\gamma$ in water and $\mathrm{N}, \mathrm{N}$ dimethylformamide are given in Table 2.

TABLE 2. Enthalpies and entropies of complexation of $\alpha$ and $\gamma$ cyclodextrins with $p\left(\mathrm{pOHPhN}_{2}\right) \mathrm{B}^{-}$in water and $\mathrm{N}, \mathrm{N}$ dimethylformamide at $298.15 \mathrm{~K}$ ( $r$ ef 51 ).

\begin{tabular}{|c|c|c|c|c|}
\hline & & & & \\
\hline & $\begin{array}{l}\Delta_{\mathrm{C}} \mathrm{H}^{\circ} \\
\mathrm{kJ} \mathrm{mol}^{-1}\end{array}$ & $\begin{array}{l}\Delta_{C} S^{0} \\
\mathrm{JK}^{-1} \mathrm{~mol}^{-1}\end{array}$ & $\begin{array}{l}\Delta_{\mathrm{CJ} \mathrm{Hol}^{\circ}} \\
\text {-1 }\end{array}$ & $\begin{array}{l}\Delta_{c} \mathrm{~S}^{0} \\
\mathrm{JK}^{-1} \mathrm{~mol}^{-1}\end{array}$ \\
\hline $\mathrm{H}_{2} \mathrm{O}$ & -29.13 & -28.2 & -20.44 & 10.5 \\
\hline DMF & $-15.53(-19.30)$ & $20.8(20.8)$ & $-17.17(-19.30)$ & 20.8 \\
\hline
\end{tabular}

Analysis of the data shown in Table 2 reflect two different patterns.

a) In water, $\Delta_{\mathrm{c}} \mathrm{H}^{\circ}$ and $\Delta_{\mathrm{c}} \mathrm{S}^{\circ}$ values are ligand dependent. It is known from our own work (ref 49 ) as well as from previous work on azo dyes (ref 53) that complex formation between these anions and CD's in water takes place through the inclusion of the $p \mathrm{OHPhN}{ }_{2}$ group in the cavity of the ligand. Therefore, the more positive $\Delta_{\mathrm{C}} \mathrm{H}^{\circ}$ and $\Delta_{\mathrm{c}} \mathrm{S}^{\circ}$ values observed for $\gamma$ relative to $\alpha$ cyclodextrin must be attributed to a higher release of water from $\gamma \mathrm{CD}$ with respect to $\alpha \mathrm{CD}$ during the process of complexation.

b) In $\mathrm{N}, \mathrm{N}$ dimethylformamide, the $\Delta_{\mathrm{C}} \mathrm{H}^{\circ}$ and $\Delta_{c} \mathrm{~S}^{\circ}$ values for this anion (or any other anion in this series) are almost the same. This is a strong indication that the cavity of the ligand is unlikely to participate in the complex formation of CD's and these anions in this solvent. This could be attributed to: 
(i) A strong ligand-solvent interaction

with DMF molecules included in the ligand cavity. These interactions should be reflected in the thermodynamic parameters of transfer of the host molecules from water to $N, N$ dimethylformamide. These values (refs $49 \& 50)\left(\alpha C D ; \Delta_{t} G^{\circ}=1.74 \mathrm{~kJ} \mathrm{~mol}^{-1}\right.$, $\Delta_{\mathrm{t}} \mathrm{H}^{\circ}=-44.34 \mathrm{~kJ} \mathrm{~mol}^{-1} ; \Delta_{\mathrm{t}} \mathrm{S}^{\circ}=-155.9 \mathrm{JK}^{-1} \mathrm{~mol}^{-1} ; \gamma \mathrm{CD} ; \Delta_{\mathrm{t}} \mathrm{G}^{\circ}=1.56 \mathrm{~kJ} \mathrm{~mol}^{-1} ; \Delta_{\mathrm{t}} \mathrm{H}^{\circ}=-59.79 \mathrm{~kJ}^{\circ}$ $\mathrm{mol}^{-1} ; \Delta_{t} \mathrm{~S}^{\circ}=-205.8 \mathrm{JK}^{-1} \mathrm{~mol}^{-1}$ ) are atypical for the transfer of nonelectrolytes from water to $\mathrm{N}, \mathrm{N}$ dimethylformamide. In fact, $\Delta_{\mathrm{t}} \mathrm{H}^{\circ}$ and $\Delta_{\mathrm{t}} \mathrm{S}^{\circ}$ values are just the opposite to those obtained for the transfer of other macrocyclic ligands (cryptands and crowns) (refs 18 \& 54) and reflect a strong $\mathrm{CD}-\mathrm{DMF}$ interaction. $\Delta_{t} \mathrm{H}^{\circ}$ values reflect a definite size effect with an increase in stability (in enthalpic terms) in DMF as the size of the cavity increases. Therefore, inclusion of the solvent in the ligand cavity is likely to occur. If this is the case, unless the energy requirements are met to remove the solvent from the cavity, formation of inclusion complexes in this solvent is unlikely to occur.

\section{(ii) Strong interaction between these anions and the hydroxyl groups of CD's (outside the cavity)}

The complexation process can be visualised as the transfer of the anion to a rich alcoholic medium (the ligand). Thus, thermodynamic data for the transfer of the anion from DMF to an alcohol methanol) could assist in the interpretation of the process. These values are indicated in Table 2 (between brackets). The agreement between transfer and complexation data is remarkable. Therefore, it was concluded that equatorial (or lid) type complexes between these anions and CD's are likely to occur in $N, N$ dimethylformamide. Equatorial or lid type complexes between cyclodextrins and guest substrates have been reported elsewhere (refs 55 \& 56). A schematic representation of inclusion complexes in water and lid type complexes in $N, N$ dimethylformamide is given.

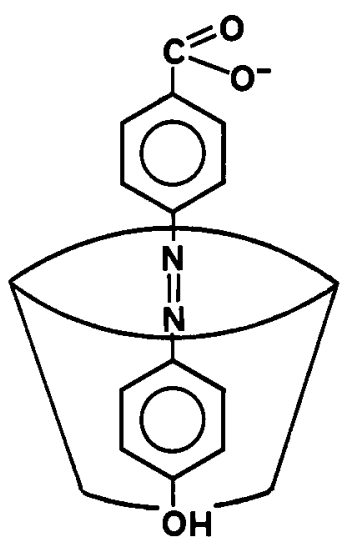

Axial complex $\left(\mathrm{H}_{2} \mathrm{O}\right)$

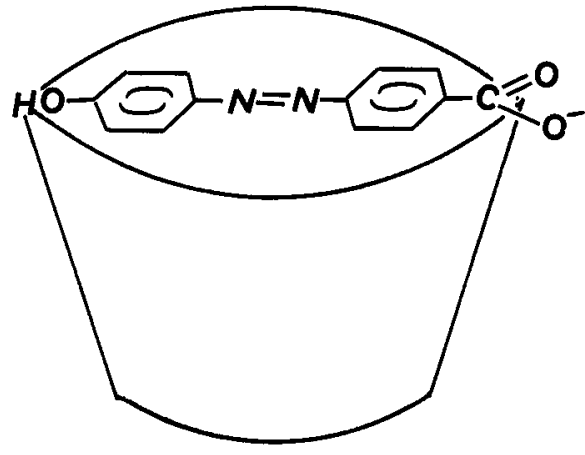

Equatorial or lid type complex (DMF)

\section{CONCLUSIONS}

In the preceding sections an outline of some of the topics currently studied at the Thermochemistry Laboratory at Surrey have been given. Undoubtedly, transfer data for the host and guest components of the system have contributed significantly to increase understanding of these important complexation processes. These data have been derived from solubility and calorimetric measurements. The determination of reliable solubility and calorimetric data is by no means a trivial process and their significance justifies many more efforts in this direction. I feel strongly that the scope of calorimetry has not generally received the appreciation that it deserves, particularly in the UK. I have outlined in this paper our inferences of complex structure from thermodynamic data. The possibility of establishing the active sites of the host molecule from transfer data for the guest to solvents containing functional groups common to the host, should be further explored. This approach may have useful implications in molecular recognition processes.

\section{REFERENCES}

1. C.J. Pedersen, J. Amer. Chem. Soc. 89 , 2495 (1967).

2. C.J. Pedersen, J. Amer. Chem. Soc., 89,7017 (1967).

3. J.M. Lehn, Struct. Bond., 16, 1 (1973).

4. J.M. Lehn, Accounts Chem. Res, 11, 49 (1978).

5. D.J. Cram and J.M. Cram, Science, 183,803 (1974).

6. Y. Chao and D.J. Cram, J. Amer. Soc. 98,1015 (1976).

7. D.J. Cram and J.M. Cram, Accounts Res. Chem. 11, 8 (1978).

8. J.S. Bradshaw, G.E. Maas, R.M. Izatt and J.J. Christensen, chem. Revs. 79 , 37 (1979).

9. J.J. Christensen, D.J. Eathough and R.M. Izatt, Chem. Revs.. 74, $351(1974)$.

10. R.M. Izatt, J.S. Bradshaw, S.A. Nielsen, J.D. Lamb, J.J. Christensen, and D. Sen, Chem. Revs. 85, $271(1985)$.

11. F. Vögtle, W.M. Müller and W.H. Watson, Top. Curr. Chem., 125, 231 (1984). 
12. J.D. Lamb, R.M. Izatt, J.J. Christensen, D.J. Eathough, 'Coordination Chemistry of Macrocyclic Compounds', G.A. Melson, Plenum Press, New York (1979).

13. F. de Jong and D.N. Reinhoudt, 'Stability and Reactivity of Crown-Ether Complexes', Adv. in Phys. Org. Chem., Vol. 17, Academic Press Inc., London (1981).

14. B. Dietrich in 'Inclusion Compounds', Eds. J.L. Atwood, J.E. Davies and D.D. MacNicol, Academic Press, Vol. 2, (1984).

15. L.F. Lindoy, 'The Chemistry of Macrocyclic Ligand Complexes', Cambridge University Press (1989).

16. B.G. Cox, J. Garcia Rosas and H. Schneider, J. Amer. Chem. Soc. 103, 1384 (1981).

17. B.G. Cox, Annu. Rep. Progr. Chem. Sect. C. Phys. Chem., 81,43 (1984).

18. A.F. Danil de Namor and L. Ghousseini, J. Chem. Soc. Faraday Trans I 80,2349 (1984).

19. A.F. Danil de Namor and L. Ghousseini, J. Chem. Soc., Faraday Trans I, 81, 781 (1985).

20. A.F. Danil de Namor and L. Ghousseini, J. Chem. Soc., Faraday Trans I, 12 , 3275 (1986).

21. A.F. Danil de Namor, J. Chem. Soc., Faraday Trans I, 88, 2441 (1988).

22. A.F. Danil de Namor and F. Fernandez Salazar, J. Chem. Soc., Faraday Trans I, $\underline{88}, 3539$ (1988).

23. R. Alexander and A.J. Parker, J. Amer. Chem. Soc. 89 , 5549 (1967).

24. R. Alexander, A.J. Parker, J.H. Sharp, and W.E. Waghorne, J. Amer. Chem. Soc. $\underline{94}, 1148$ (1972).

25. O. Popovych, Crit. Rev. Anal. Chem. 1 , 73 (1980).

26. Y. Marcus, Rev. Anal. Chem. 5,53 (1980).

27. B.G. Cox, G.R. Hedwig, A.J. Parker and D.W. Watts, Aust. J. Chem. 27, 477 (1974).

28. M.F. Lejaille, M.H. Livertoux, G. Guidon and J. Bessiere, J. Bull. Soc. Chim. France, 1-373 (1978).

29. J. Bessiere and M.F. Lejaille, Anal. Lett., 12, 753 (1979).

30. M.H. Abraham, A.F. Danil de Namor and W.H. Lee, J. Chem. Soc. Chem. Comm. 893 (1977).

31. M.K. Chantooni and I.M. Kolthoff, J. Soln. Chem., 14, 1 (1985).

32. A.F. Danil de Namor, L. Ghousseini and W.H. Lee, J. Chem. Soc., Faraday Trans I, 81, 2495 (1985).

33. A.F. Danil de Namor, F. Fernandez Salazar and P. Greenwood, J. Chem. Soc., Faraday Trans I. 83, 2663 (1987).

34. A.F. Danil de Namor, T. Hill, R.A.C. Walker, E. Contreras Viguria and H. Berroa de Ponce, J. Chem. Soc., Faraday Trans I 84,2551 (1988).

35. A.F. Danil de Namor, and A. Aguilar Cornejo, work in progress.

36. S. Ahrland, Pure Appl. Chem. 54, 1451 (1982).

37. A.F. Danil de Namor, M.C. Ritt and J. Kröber, unpublished results.

38. A.F. Danil de Namor, M.C. Ritt, M.J. Schwing-Weill and F. Arnaud-Neu, J. Chem. Soc., Faraday Trans I 86,89 (1990).

39. J.M. Timko, S.S. Moore, D.M. Walba, P.C. Hiberty and D.J. Cram, J. Amer. Chem. Soc., $\underline{99}$, 4207 (1977).

40. R.M. Izatt, J.D. Lamb, N.E. Izatt, B.E. Rossiter, J.J. Christensen and B.L. Haymore, J.Amer. Chem. Soc., 101, 6273 (1979).

41. A.F. Danil de Namor, M.C. Ritt, M.J. Schwing-Weill, F. Arnaud-Neu and D.F.V. Lewis. To be submitted for publication.

42. A.F. Danil de Namor, M.C. Ritt, M.J. Schwing-Weill, F. Arnaud-Neu and D.F.V. Lewis, J. Chem. Soc. Chem. Comm., 116 (1990).

43. A.F. Danil de Namor, M.C. Ritt, M.J. Schwing-Weill, F. Arnaud-Neu and D.F.V. Lewis. XXI International Conference on Solution Chemistry, Ottawa, Canada, August 1990.

44. W. Saenger, Angew. Chem. Int. Ed. 19, 344 (1980).

45. K. Uekama, Pharm. Soc. Jpn., 10, 857 (1981).

46. W. Saenger, Inclusion Compounds, Eds. J.L. Atwood, J.E. Davies and D.D. MacNicol, Academic Press, New York, Vol. 2, (1984).

47. Y. Hamada, N. Nambu and T. Nagai, Chem. Pharm. Bull., 23, 1205 (1975).

48. K. Koizumi, K. Mitsui and K. Higuchi, Yakugaku Zasshi, 94, 1515 (1974).

49. A.F. Danil de Namor, R. Traboulssi and D.F.V. Lewis, J. Chem. Soc. Chem. Comm., 751 (1990).

50. A.F. Danil de Namor, R. Traboulssi and D.F.V. Lewis, J. Amer. Chem. Soc., (1990) in the press.

51. A.F. Danil de Namor, R. Traboulssi and F.H. Marquardt, J. Chem. Soc. Faraday Trans I $\underline{86}$, 1067 (1990).

52. A.F. Danil de Namor, R. Traboulssi and M. Salomon, J. Chem. Soc. Faraday Trans I, $\underline{86}, 2193$ (1990).

53. F. Cramer, W. Saenger and H. Ch. Spatz, J. Amer. Chem. Soc, 89, 14 (1967).

54. A.F. Danil de Namor and F. Fernandez Salazar, unpublished results.

55. M. Komiyama, J. Amer. Chem. Soc. 111, 3046 (1989).

56. O.S. Tee and J.J. Holven, J.Amer. Chem. Soc., 111, 8318 (1989). 